Viktorija Mano

\title{
Domestic elite support for reforms in transition economies: the case of North Macedonia
}

\begin{abstract}
To what extent do domestic elites allow the intervention of international institutions to influence domestic economic reform? This question cannot be answered without considering the role of national elites in accepting international institutions as a means to advance their own interests. This article provides a critique of the neoliberal reform process in transition economies and examines how these policies found support among the people of North Macedonia. This is done by exploring the construct of neoliberal discourse during North Macedonia's reform process through an analysis of policy documents, interviews with key actors and the country's privatisation policy. The findings confirm that mass support for reform is influenced by the attitudes of the elite. The main implication for policymakers is, above all, for client-countries and their policy-makers to be more critical of the agenda set by foreign experts for small economies. The article also highlights the need for IMF experts to recognise in full the nuances in targeted contexts and to ensure that policy programmes are relevant by being contextspecific.
\end{abstract}

Keywords: elites, hegemony, IMF, North Macedonia, neoliberalism, transition, privatisation

Introduction

Many attempts at economic reforms were made throughout the 1990s in transition economies of varying sizes (Grugel and Riggirozzi 2012). The countries that emerged from the collapse of the Soviet Union, as well as the social democracies created after the disintegration of Yugoslavia, opened their doors, either voluntarily or in response to outside pressures, to different versions of neoliberal policies or, otherwise, adjusted their existing policies accordingly (Harvey 2007). The 'free market' construct was therefore presented as the solution for rebuilding socialist economies through the concept of IMF programmes promoting economic reform (Chossudovsky 1997; Pop-Eleches 2009; Vreeland 2003).

Although scholars have acknowledged the benefits domestically of collaborating and joining with international institutions (Mansfield and Pevehouse 2006; Vreeland 2003), existing work has not investigated the circumstances that contribute to a strengthening of the relationship between the international institutions and domestic elites. Given that this trajectory of economic and political change in central and south-east Europe has been presented as the cornerstone of analysing developments in small economies, a fine-grained understanding of its processes is indispensable to 
current knowledge when investigating the role of elites in the neoliberal reform process. I examine how elites in transition economies create support among the public for the otherwise unfavourable reforms suggested by the international institutions (Baccini and Urpelainen 2014). The variation that exists between countries in the level of popular support for economic reforms may also be a result of the extent to which domestic elites are themselves supportive of the reform process (Chhibber and Eldersveld 2000; Vreeland 2003). The 'Washington consensus', which lies in favour of market orthodoxy, has often provided the basis for a consensus between elites at domestic level, leading to a more pro-market discourse and sentiment in various countries (Baker 2003; Habib and Padayachee 2000). It is argued that, when elites in countries are more approving of the reform process, there is a high probability that economic reforms will be supported by the population (Chhibber and Eldersveld 2000; Vreeland, 2003).

This article investigates the nature of the involvement of the IMF, the key player and propagator of neoliberal views in early post-communist transition economies in Europe, using North Macedonia - a newly-independent, small ex-Yugoslav republic situated in the Balkans ${ }^{1}$ - as an illustrative case. This contributes to our understanding of ex-Yugoslav transition economies which remain under-studied. In line with the logic of discourse theory, the article seeks to highlight the rhetorical representations of the neoliberal discourse embedded in IMF documents and participant ${ }^{2}$ inter- $^{-}$ views by applying discourse analysis. It also draws specific attention to the representation of context specificities through the IMF's discourse during North Macedonia's pro-market reform process during the 1990s. By doing so, it intends to orient the reader towards the ways in which the supposedly effective development policies implemented in transitional economies have been projected by the elites ${ }^{3}$ via reform discourse.

North Macedonia presents a particularly interesting case from which to explore the nature of reform processes because of the evidence which suggests that the macroeconomic restructuring applied to the country, in line with the neoliberal policy agenda, contributed to the prolonged transition that it experienced (Abdullai and Sinani 2012). By situating the study in the context of North Macedonia, this article attempts to offer an understanding of the region's ongoing, conflictive reform process and the contradictory involvement of the IMF throughout the market liberalisation process. In addition to attempting an understanding of the IMF's involvement in

1 Editorial note: this article covers the period when the country now called North Macedonia, following the 2018 Prespa agreement, was known - as a result of the naming dispute with Greece which led to the Prespa agreement - as the Former Yugoslav Republic of Macedonia (or FYROM). However, we have adopted its current name throughout our text.

2 Research partners (academics, politicians and economists) are drawn from among those who, in the 1990s, were closely following the course of the negotiations with the IMF and the overall transition period.

3 The term 'domestic elites' is used throughout the article to refer to political and bureaucratic officials who have decision-making responsibilities in government and whose decisions become authoritative within society (Grindle and Thomas 1989). It is a term used interchangeably with 'decision-makers', 'policy-makers' and 'policy planners'. 
the economic reform process in North Macedonia, this article attempts to shed light on the neoliberal reform process in Balkan transition economies which has itself remained underexplored.

The following section highlights the theories which relate to popular support for neo-liberal economic reforms and the role of the IMF in the economic reform process in North Macedonia, drawing largely on research findings that were contemporary at the time of the reform period. The main discussion section uses documents and interviews from which to develop a critical evaluation of the IMF's economic reform programme as well as to analyse the political and economic factors which have contributed to how the domestic elites obtained support for these economic reforms in North Macedonia. The article concludes with some reflections on the politics of neoliberal economic reform as well as this research study's contribution to the wider research area and its impact.

\section{Popular support for economic reforms}

The neoliberal reform process involves the implementation of market-oriented reforms which, in turn, leads to a change in the national political policy process (Armijo and Faucher 2002). This alteration has implications for the practices of all the major players in one economy - the state and its bureaucracy; the political and economic elites; the appropriate institutions; and the international financial community (Armijo and Faucher 2002; Przeworski 1996). The term 'reform' is used advisedly throughout this paper. Those promoting these sorts of policies are attempting to bring about reform, a change that will lead to a more desirable outcome than the current one (Bratton and Mattes 2001). However, such policies may not always achieve the goals intended by their proponents and the notion of a 'desirable' outcome can often be a subjective one.

Most transition countries liberalised their markets by following similar reform packages based on macroeconomic stabilisation policies, the liberalisation of the banking sector, the opening of markets to foreign direct investment and trade, the privatisation of state-owned enterprises and market deregulation (Baker 2003; Bratton and Mattes 2003; Desai and Olofsgård 2006). Similarly reforms were initiated within these countries during a crucial political transformation of systemic change: the break-up of the USSR; the disintegration of Yugoslavia; and the eclipse of authoritarian rule in some Latin American countries (Desai and Olofsgård 2006). Most of the academic literature in the past two decades has argued that obstacles to growth recovery are not a matter of the reforms not being implemented at all, but that they are being partially implemented by the political elites so that they can benefit from arbitrage between the reformed and unreformed parts (Hellman 1998). According to research in many post-socialist and post-communist countries, oligarchs or middlemen are perceived as elites who took advantage of pre-set exchange rates, unregulated prices and underbidding for natural resources or who exploited relationships with ministries, privatisation agencies and state-owned banks (Aslund 2000; Shleifer and Treisman 2000). These events led to support for reforms being undermined by people who resented the newly-rich or those who obtained their wealth or who benefited from illegal activities during the reform process (Åslund et al. 2002). 
Relatively little research has been undertaken to investigate the determining factors of support among the public and the authorities for market reforms. Some of these studies focus on the political characteristics of the countries under investigation that have created a favourable environment for adopting the suggested economic reform programmes (Armijo and Faucher 2002; Desai and Olofsgård 2006, Haggard 1995; Haggard and Kaufman 1990; Nelson 1990); while others focus on the economic circumstances that have pushed domestic leaders to ask for financial support through the form of IMF loans, which are subject to certain conditions (Bacanovic and Jovanova 2011; Johnson et al. 1997; Micevska et al. 2002).

Many transition countries (in eastern Europe, CIS,${ }^{4}$ south-east Europe and Latin America) have initiated market reforms under different conditions, but some similarities can be drawn between the processes. Gibson (1997) argues that popular support for reforms was achieved in the Argentinian and Mexican economies through the government's intention to build coalitions across social groups through targeted policy measures. Similarly Moore (1997), who studied the Sri Lankan case, and Roberts and Arce (1998) in that of Peru, found that popular support can be attained by implementing targeted economic incentives benefiting different segments of the population. Therefore, a common conception appears to be that the extent of support for economic reforms is largely dependent on the incentives that the regime offers to specific social groups in the target economy (Gibson 1997; Moore 1997).

However, support for reforms may not always be as straightforward as it appears. For instance, in some countries, sentiment revolves around the idea that market reforms are the cause of an increased level of corruption, political instability, intense economic vulnerability and a fall in living standards (Baker 2003). These responses in reforming economies can pose risks that undermine support for market reforms (Desai and Olofsgård, 2006). Nevertheless, there is consensus among researchers that:

popular support is necessary for ensuring legitimacy and sustainability of successful economic reforms (Chhibber and Eldersveld 2000).

Because economic reforms are usually initiated at the level of the political elite, it appears safe to suggest that investigating support for and the popularity of economic reforms amongst the national elite is important. This is particularly so because the economic reform process means an alteration of the government's role in the economy. Hence any reconfiguration of economic policies would have to meet the interests of particular political actors or social groups such as government leaders, the bureaucracy and the policy and business elite (Haggard 1995). The 'common thread' among these explanations is that support for pro-market policies is based on how individual actors perceive the benefit or cost of the reforms. This means that there is a higher possibility of gaining support for neoliberal reforms from those who directly benefit from them in comparison with their counterparts who may not directly benefit (Chhibber and Eldersveld 2000; Habib and Padayachee 2000).

4 The Commonwealth of Independent States (CIS) was formed when the Soviet Union was dissolved in 1991. 
In light of this, this article makes a contribution by offering an understanding of the benefits arising from neoliberal reform policies by focusing on the role played by local economic and political elites in supporting the economic reform processes propagated by foreign experts. I take into consideration both the economic and the political factors and the role of domestic elites in creating an environment of acceptance of the economic reforms propagated by international institutions such as the IMF. Given the under-researched nature of the Balkan region's relationship with the IMF during its transition from socialism to a free market economy, the article makes an attempt to shed light on the contemporary literature as well as to develop an empirical contribution to the body of literature going forward by drawing on data from North Macedonia whose economic reform process forms part of the wider transitional issues raised by ex-Yugoslav economies.

Within these developments, North Macedonia led the ranking tables among transition economies in terms of monetary stabilisation by the end of the 1990s. However, this does not seem to have been reflected in the country's subsequent economic growth to the extent that the country was, a decade later, lagging in ways similar to its more unstable regional neighbours (Lolos 2009). In fact, persistent structural problems and financial indiscipline in the country highlights that, in transition economies, stabilisation may not be sufficient for economic growth (Johnson et al. 1997).

The obvious questions that arise, therefore, focus on why the government authorities in North Macedonia allowed the implementation of economic policies which have proven to be ineffective or, alternatively, allowed the partial implementation of certain policies. Therefore, how was it possible for such reforms to find domestic support. In addressing these questions, I consider the role of the elite in welcoming alterations to economic policy as well as in influencing mass support for a sustainable economic reform process. However, it is important at the outset to explore the political and economic factors that influenced policy reform choices during the process of transition in North Macedonia. It is through this that I attempt to understand the role of the domestic elites in sustaining and in influencing mass support for the reform process propagated by the IMF.

The political and economic factors which set the scene for reform support in North Macedonia

Economic reforms, regardless of their predicted effects, have consequences that spread throughout the economy creating benefits for some and difficulties for others. For a reform to be successful and durable, governments must ensure support for the programme. Therefore, any analysis of reform requires a focus on the interest groups who have a stake in it and a consideration of both the political and the economic factors that set the scene in which the economic reform process takes place. Political factors include the type of the political regime, the process of transition to and from democracy and the party system which operates in the new democracies; while the economic factors encompass economic vulnerabilities (fear of crisis), the collective memory of policy-makers and the level of external influence (Chhibber and Eldersveld 2000). 


\section{The political background influencing the new state}

One of the antagonistic issues in political economy is the role of the political regime that is directing the reform process. Several studies debate the ability of either authoritarian or democratic regimes to maintain and/or initiate stable pro-market reforms (Acemoglu and Robinson 2008; Haggard and Kaufman 1990) while others establish the significant effects that political institutions have on the economic outcomes of reforms (Persson and Tabellini 2006; Besley at al. 2005; Kohlscheen 2005). Many studies argue that authoritarian regimes are more successful at initiating reforms than their democratic counterparts particularly because of the weakness of young democracies in the developing world (Haggard and Kaufman 1990; Nelson 1990; Snider 1990).

The Socialist Federal Republic of Yugoslavia (SFRY), as an authoritarian regime, took advantage of long-term planning to make changes and started to move toward economic reforms in contrast to communist Soviet Union countries. The most significant period of economic reform in North Macedonia (as a part of Yugoslavia) began in 1965 and constituted mostly pro-market reforms ${ }^{5}$ (Shenkar and Von Glinow 1994). These reforms increased the openness of the economy and led to price liberalisation, signifying the shift from a planned economy to self-governing socialism. Even though authoritarian regimes are not accountable forms of rule, they do remain vulnerable to pressure from groups which might even give rise to corruption (Haggard and Webb 1993; Olson 1990). Therefore, in the period after the 1970s, leading critical thinkers of the Yugoslav Communist Party considered the market reforms to be inefficient. They felt that such reforms took the economy in the direction of turbulence and instability characterised by 'sharp trade cycles, unemployment and pay inequality' (Estrin 1991).

Various examples demonstrate that democracies also tend to be subject to pressures from interest groups when allocating budget funding for specific sectors or districts (Shepsle and Weingast 1984). Leading on from this discussion, the transition to or from democracy appears to be an important issue in some studies which show that movement from an authoritarian regime, and the related crisis, can also generate macroeconomic instabilities and less support for further reform (Haggard et al. 1991).

As a result of unstable economic development and the fears of the smaller republics of dominance by the larger ones, SFRY was in a state of continuous tension. Turbulent internal relations and unceasing economic problems led to changes in the constitution in 1974 and brought new reforms which meant the republics were considered as national states and the provinces as "constitutional elements of the federation'. To some extent, this was the first indicator of a shift from centralised governance to a more democratic dispersed power. The late 70 s and 80 s was a period of severe economic pressure which made the process of effective policy-making difficult. Industrial crisis within SFRY, the sharp fall in GDP leading to high unemploy-

5 An emerging capital market, centrally determined low interest rates, openness of the economy, liberalisation of prices, enhanced decision-making authority of firms and the decentralisation of investment funds from the state to the socially-owned banks. 
ment and the contrasting levels of development between the north and the south of the country brought this separation process to its final stage, leading to the idea of the formation of a pluralist political system in the 1990s (Risteski and Trpkova 2012). In conjunction with a significant increase in Serbian nationalism and following the death of Tito in 1980, these factors accelerated the disintegration of SFRY (Naughton 1994; North 1990).

The independence and sovereignty of North Macedonia were established by a declaration, confirmed in a national referendum in September 1991, and backed up with the formation of a democratically elected government (Bacanovic and Jovanova 2011). This period marked the transition of the country to democratic rule. Despite a new constitution (November 1991), however, the legacy effects of socialist planning in the country still prevailed. Political instabilities during the movement towards democratic rule are commonly associated with macroeconomic instability, as was the case in North Macedonia in which the economic instabilities faced by the new democratic government were the result of the politically motivated actions of its predecessors (Haggard et al. 1993). This feeds into the party system which operates in new democracies as the final political factor needing to be considered.

When investigating the impact of the transition to democracy on the economic outcomes of reforms, one may wish to distinguish between different gradations of democracy and between democracies with different electoral and party structures (Acemoglu and Robinson 2008; Rodrik 2014; Alesina and Rosenthal 1995). Research suggests that it is of great importance whether the party system is organised in such a way as to support or oppose reforms (Acemoglu and Robinson 2008). The first elections after North Macedonia's independence in 1994 saw the socialist liberal democratic alliance emerging as successful, winning 87 out of the 120 parliamentary seats (Nineski 2001). This outcome provided appropriate conditions for the dominant governing party, capable of ruling by itself, in which it could easily obtain legislative support for its suggested economic policy programme. This demonstrates the importance of the party system to cohesion in economic policy-making, as argued by Haggard and Webb (1993).

These political factors are echoed in the literature which argues that political stability and support are crucial to the reform process. However, studies also report that authoritarian regimes do not show better policy performance than democratic regimes and neither are there systematic growth differences between dictatorships and democracies (Mulligan et al. 2004; Barro 1997). Furthermore, studies based solely on assumptions about the nature of the regime do not control for other economic factors which could contribute to support for economic reforms (Chhibber and Eldersveld 2000). This is the reason for the focus in this article on both the political and the economic factors that set the scene for IMF reforms to be welcomed in North Macedonia.

\section{The economic background influencing the new state}

Economic conditions, as discussed above, also have an impact on the policy agenda that the government decides to follow and hence on its ability to support re- 
forms. Haggard and Webb (1993: 152) identify three factors which influence a government's decisions on support for reform.

The first such factor is the intensity and length of economic crisis in a country. The transition in North Macedonia unfortunately coincided with the unstable conditions caused by the wars in Croatia and in Bosnia and Herzegovina, UN sanctions against the Federal Republic of Yugoslavia and the Greek economic blockade (Ruzin 1999). Thus North Macedonia faced considerable barriers in reaching potential trade markets (Bacanovic and Jovanova 2011; Ruzin 1999).

The distributed elements of vertically-integrated production processes within SFRY saw to it that each republic specialised in an economic activity. Central industrial production in North Macedonia consisted of energy-intensive manufacturing, including iron and steel; labour-intensive production (light industries such as textiles and food processing); and the generation and distribution of electricity production ${ }^{6}$ (Micevska et al. 2002). This left the new state in a strong position to meet its basic food needs subsequent to independence, but also left it facing limited supplies of gas, oil and modern machinery (Micevska et al. 2002). Already one of the poorest republics in SFRY, output in North Macedonia actually declined even further as a result of specialisation (Mastilica 1990). These factors led, in the period immediately following independence, to the expansion of the informal economy which made up 30 per cent of the whole compared with a rate of approximately 10 per cent in other countries (Ruzin 1999).

Taking these issues into consideration, North Macedonia was in fear of the war spilling over and a further deterioration in economic conditions. Consequently the newly-elected government decided to welcome the economic reforms suggested by the IMF so as to gain much-needed financial support to survive. This reflects the argument of Webb and Shariff (1992) that newly-elected governments may be more willing to introduce fresh programmes as democratic regimes when they face crisis. Additionally, during economic crises, a redistribution of power takes place in which certain groups are weakened and others strengthened. This was the case with pro-reform groups in North Macedonia which became stronger (demonstrated through the dominant political party system) while public support for reform gathered momentum (Haggard and Webb 1993: 153).

Nelson (1990) also argues that it is the perception of politicians and policy-makers of the nature of crisis which is important. This is because they are often less likely to act when they identify the causes of the crisis as external. In the case of North Macedonia, policy-makers had come to realise that the problems were, in part, linked to the external regional turbulences (which did eventually spill over internally) but, more importantly, they also realised that the old inherited socialist economic system (an internal factor) was unable to cope and was in need of restructuring in favour of a free market system.

6 The economy of North Macedonia was dominated more heavily by industrial production (47 per cent of GDP) relative to the service sector and construction than was the case in other western economies. 
The second economic factor is the collective memory of policy-makers and politicians. Haggard and Webb (1993) highlight that economic experiences from the past represent lessons and analogies that guide elites and politicians in their decisionmaking processes. Here, collective memory relates to the efforts initiated towards reform in Yugoslavia during the 1960s as well as the structural reforms adopted under Ante Marković in 1989. These later reforms initiated the transformation of sociallyowned enterprises into forms of private capitalism which played a crucial role in the Yugoslav movement toward market-based reform (Chossudovsky 1997). The objective of these reforms was to place SFRY 'under massive privatization and dismantling of the public sector' (Schoenman 1995). Thus, over two years (1989-1990) more than 1100 companies were driven into bankruptcy or were liquidated because of their inability to remain solvent while about 600000 workers were laid off ${ }^{7}$ (Chossudovsky 1997).

Many authoritarian regimes do not exit by choice but rather under pressure from popular protest, from key economic elites and from internal division; and this was also responsible for the momentum to move SFRY away from an authoritarian regime towards a more democratic one (Haggard and Webb 1993). However, the depth of the economic pressures made the reform process unfavourable and this, coupled with the circumstances mentioned above, led to the fall of SFRY and the formation of the independent country of North Macedonia.

Collective memory is particularly applicable in countries which have experienced high levels of hyperinflation (due to past policies) leading to economic distress. This was the case with SFRY (Rodrik 2014). Such economic conditions prove to be crucial given their impact on decision-making about the future direction of economic policy. Sikkink (1990) argues that eliminating the effects of such past legacies requires alterations in policies and institutional changes which would minimise the possibility of undesirable policies re-emerging. However, the reforms imposed by the IMF and World Bank during the existence of SFRY were naturally extended to the successor states. Subsequent to North Macedonia's independence, its firms needed to operate within a competitive market with significantly lower demand and a concomitant level of supply; this implied a need for a change in old habits and a movement towards democratic neoliberal reform (Bartlett 2009). Furthermore, enterprises were required to cut costs to remain competitive in markets that were, in the first place, significantly smaller and, in the second, much more competitive. ${ }^{8}$ Therefore, enterprises made cuts in their labour costs, significantly increasing the unemployment rate. This left the economy vulnerable and the relatively high wages related to higher prices, together with the high unemployment rate, resulted in an inflation rate which reached 608.4 per cent in 1993 (Micevska et al. 2002).

External influence is the third economic factor that may influence support for reforms. Haggard and Webb (1993) argue that external economic and political factors

7 By 1990, GDP had collapsed to a growth rate of -7.5 per cent while in 1991 it declined by a further 15 per cent (Chossudovsky 1997).

8 Due to the dissolution of SFRY, North Macedonia was left to satisfy the demand of a significantly smaller Yugoslav market than before while dealing with the much tougher competitiveness of European markets. 
might influence domestic policy-making in developing countries through three dominant channels. I choose to focus here on the international networks that might influence policy choice.

Scholars have found that foreign advisers, training programmes, governmentsponsored exchange programmes and work experience in multinational corporations can aid in the transmission of policy-relevant knowledge (Kahler 1992; Sikkink 1990). This is closely related to the external actors which can influence policy directly through loan conditionality (Haggard and Webb 1993). It is also argued that international actors have an impact on the international economic and political dependency of new democracies in the process of decision-making about reforms (Grindle and Thomas 1989). Therefore, international financial institutions may have leverage at the outset through conditions imposed on governments even where the success of the programme depends on domestic negotiations and implementation.

Having covered the political and economic factors that might have contributed to setting the scene and creating the necessity for urgent economic reforms, it is of great importance to provide further insight into the roles that the external actors (such as the IMF) played, in conjunction with the domestic elites, in the transition of the economy of North Macedonia.

\section{The involvement of the elites in the North Macedonian reform process}

The starting point for this section of the analysis is to identify and uncover the discourse of the IMF as a means of highlighting and discussing its motivations and involvement in the reform process in North Macedonia and, perhaps, in other small transition economies. This is based on the logic that the IMF is a body that is connected to state power and seeks to shape economies in ways favourable to its own interests and agendas (Hameiri and Jones 2017).

In essence, the analysis of the data in this section is aimed at two goals. First, it seeks to investigate the extent to which the IMF has adopted a 'one size fits all' approach in the case of the North Macedonian economic reform process. This is tackled by analysing the discourse of the IMF in its official reports. Second, the section evaluates the ways in which these universal policies may have received support in North Macedonia in spite of indications that they were not sympathetic to the local context (Risteski and Trpkova 2012). This second aim is addressed by detecting the extent to which the key economic factors suggested by the literature surfaced in the discussions and interviews held with our research partners. Thereafter, I uncover the politics of economic reform rooted in the role played by domestic elites in the course of determining their own importance in obtaining support for neoliberal reforms.

\section{The IMF's role in the policy reform process}

The transition to capitalism has prompted research about the optimal implementation of reforms, with advocates arguing for three elementary steps that need to be undertaken by transition economies in the initial stages of their pro-market reforms privatisation, price liberalisation and stabilisation (Sachs 1995; Shleifer 1997). This study's findings from a documentary analysis of IMF reports on its involvement in 
North Macedonia suggest that the implementation of reforms and policies initially focused on ensuring macroeconomic stability before promptly moving to structural reforms:

The primary challenge for economic policy in the period ahead is to stabilize the economy as a necessary precondition for the successful implementation of a much-needed program of structural reform. (IMF 1993/171: 10)

Specifically, since independence the economy of North Macedonia was subjected to macroeconomic stabilisation reforms, structural reforms and privatisation, as well as an evaluation of the effectiveness of the implemented policies within a period of only two years:

privatization entailed no more than a formal transfer of ownership rights to existing workers and worker-elected managers, suggesting that there has been no fundamental change in the financial conduct of these enterprises. (IMF 1995/175: 13)

Opponents have identified the limitations of the rapid and universal approach used by the IMF, suggesting that it is costly rather than beneficial as regards the client-country's economy and its people (Goldman 1994). In other words, by proposing a general policy prescription, the IMF is simplifying the individual situations of each country. Broadly speaking, the IMF's policies often disregard local contexts, instead applying a quick-fix approach to the issues that obstruct market liberalisation. IMF reports demonstrate the use of a mainstream discourse which over-simplifies the effects of the implemented reforms and rarely acknowledges the indirect, non-linear effects that might be induced by them.

North Macedonia had no access to neighbouring trade partners (due to regional wars, embargos and poverty-stricken neighbours); no monetary independence until 1992; and it suffered from inadequate infrastructure, poor institutionalisation and enormous inflationary pressures in 1993 (608.4 per cent). Furthermore, it had neither mint nor stock exchange until 1995 (Bacanovic and Jovanova 2001; Micevska et al. 2002). However, the policy measures suggested by the IMF were based on its standard prescriptions (tight monetary policy, bank rehabilitation and structural reforms). To avoid 'hyperinflation' and 'to prevent the elimination of selective credits leading to a liquidity crisis in banks...', 'tight monetary policy' was required alongside the rehabilitation of 'the banking system' (IMF 1993/171). Additionally, it asserted that there was a requirement for 'strong wage control... to prevent output losses' and that 'public sector recourse to the banking system needed to be avoided' (IMF 1993/171: 11). In this case, the IMF did appear to acknowledge the specificity of the macroeconomic context:

The FYRM is presently confronted with acute macroeconomic imbalances that have an important part of their origins in the political crisis in the region. (IMF 1993/171: 10)

9 Please note that the IMF press releases referenced and quoted from in this section and the next are, unfortunately, no longer available on the organisation's own website. 
However, the subsequent evaluation by the IMF of the implemented policies follows a traditional economic perspective - the presence of a direct cause and effect relationship between the implemented policies and their outcomes, demonstrating a disregard of the specificities of the context, before concluding that:

.... a significant recovery was unlikely in 1994, without improved access to traditional markets and transhipment routes. (IMF 1994/4: 3)

Furthermore, the right path towards economic stability lay in the direction of:

much tighter monetary policy and restoration of budget discipline conditioned by implementation of broad-based reforms... around privatization and bank rehabilitation. (EBS 94/4:1)

In fact, in line with Stiglitz's (2002) argument, it appeared through its approach to its analysis that the IMF had not fully comprehended that there was a significant amount of complexity in the cause and effect relationship which it acknowledged existed between its policies and their outcomes.

\section{The support of the elite for policy reforms}

Despite the apparent contradictions of the policy prescriptions outlined in the previous section, the authorities in North Macedonia seemed simply to acquiesce to the IMF's suggested set of reforms. There was very little evidence to suggest that they questioned the economic and socio-political repercussions these reforms would have on the wider stability of the country and the region:

\footnotetext{
The authorities acknowledged that lack of fundamental structural reforms had been the root cause of the problems of high inflation and economic stagnation characteristic of the former SFRY... In this respect, they [the authorities] noted that a liberal trade regime and a flexible exchange rate policy were key prerequisites for a successful reorientation towards new markets. (IMF 1993/171: 9)
}

This raises the question of how much support was obtained for these reforms to be allowed to be implemented in North Macedonia.

Through my interviews focusing on the domestic elite involved in the transition process, it is evident from the material gathered that they played an important role in shaping policy and the institutional outcomes of this since they were able to appreciate the contextual factors and what constituted an appropriate policy-making process. To understand the extent to which policy elites operate in an autonomous way and how decision-making and agenda-setting is influenced, the three main economic factors identified above are discussed in what follows. I argue that these factors further account for the reasons behind the support exhibited by the domestic elites towards the reform programme.

What I am trying to identify here is the increased willingness of the North Macedonian authorities to implement reform and induce the public to accept the impact of the reform measures. In interviews, research partners identified some of the factors that may have shaped the terrain in North Macedonia towards embracing the IMF's 
policy reforms. First, respondents identified the enduring length of the crises being experienced. Participants reflected on the economic and political restructuring of the Yugoslav regime in the 1970s (due to dissatisfaction among the republics with centralised power) as the starting point for the disintegration of the regime. This, along with the actual ending of SFRY and the war were regarded as the main factors that led to:

the low confidence and unpreparedness of the North Macedonian authorities to withstand the upcoming economic and political turbulences. (IK)

Other interviewees linked this to:

Nostalgia for a perceived era of stability and fear of the economic and political crisis in the regions spilling over in North Macedonia. (SP, IK, TN)

Respondents felt that support for reform policies was urgently necessary because 'the country was struggling to survive on its own' due both to the inherited difficulties and to being unprepared for functioning on its own. Additionally the country:

needed outside support and finances to be able to overcome the difficulties, which assisted in the creation of a more positive atmosphere for international experts to provide policy support. (GS)

The fear of the spillover effects of the violent disintegration, an inexperienced government and the youthfulness of its democracy created a lack of confidence and a certain lack of capacity by the authorities of North Macedonia to reject some of the inappropriate policies suggested by the IMF. Societal pressures and interests, historical contexts and bureaucratic capability, together with the fear of an even more severe crisis, were among the factors that contributed to this perception of inability.

In view of the economic and political instabilities of North Macedonia's past, it is argued that the economic failures that characterised attempts to restructure and retain SFRY moulded the views of policy-makers regarding policy reforms (Haggard and Webb 1993). Thus, previously unsuccessful policies (or policies which were nonfavoured by the people), such as the market reforms that featured in SFRY in the 1980s (including the reforms under Marković) were perceived by the elites as lessons, but also shaped their perceptions of the importance of creating an environment of support for policy reforms due to the potential presence of collective memory. Even though the research partners did not explicitly refer to collective memory as a factor which influenced the choices of the policy elites, the policy agenda process reflected this and also propagated a consideration of the 'greater good' of the country when considering the reforms. This idea of the 'greater good' is perceived to create a favourable environment amongst the people to support a reform process. This factor, coupled with the 'fear of a crisis spilling over and the lack of confidence among the North Macedonian authorities' was responsible for pushing the policy elites to seek urgent support from international experts (IK, GS). 
Nevertheless, the research partners did tend to criticise the elites, foreign experts and the international financial bodies (especially the IMF) for being too harsh and rushed with their suggested policies. For example, some argued that the policy elites:

are guilty of allowing the IMF to play an important and dominant role in the transition process of the North Macedonian economy, (GP)

while others characterised the transition process - especially the privatisation of state-owned companies - as 'a tycoon criminal process' (GP, WB).

Having said this, the role of the international actors and the over-reliance on them of small transition economies in managing the policy reform process is of great importance. Given that North Macedonia had only recently become an independent country (1991), the involvement of the policy elites reassured the public that the 'greater good' (rather than personal interests) was what was being taken into account in the policy-making process. Research partners explained that the aim of the policy elites was to 'express concerns about the particular regime' by sharing an awareness of the 'importance for the country's survival' and their own responsibility for this (IK, NP, TN). Thus, the 'critical thinkers' of the first North Macedonian government (which represented the country's elite society) did, to an extent, prepare the terrain for a public welcoming of the IMF's suggestions and loans.

Furthermore, a questioning of:

the country's ability to survive economic and political domestic turbulences (STP $)^{10}$

indicated that the leadership was unequipped and would benefit from the help of outside experts to assist in its development agenda. In this way, interviewees pointed out that the country had become perceived by the IMF as 'easy prey', ${ }^{11}$ while the domestic policy elites later became key players in creating support for a smooth negotiation process with the IMF. The IMF experts, in response, became engaged in bureaucratic interactions within the country, as elsewhere in other transition economies, by suggesting appropriate policy solutions. Thus, IMF expert analysts, influenced by the technical analyses of the problem they themselves had undertaken, were then in a position to advise on what was the 'best' solution to the problem. The policy elites were thus considered by respondents to have been:

captivated by the neoliberal doctrine that the IMF knows what is best for the North Macedonian economy, $(\mathrm{KMG})^{12}$

leading to them becoming perceived as the 'extended hand of neoliberal doctrine' or 'a group of promoters of IMF policies' in North Macedonia (WB, GP, SP).

10 An academic and politically active figure in latterday North Macedonian politics.

11 As argued by Sen (2015) about the different forms of imperialism exhibited by the developed over the developing world in his work on imperialism during the post-colonial era.

12 An academic, not politically active. 


\section{The support of the elites in practice - the example of privatisation}

Having discussed the three main factors that influenced the policy elites, and thereafter the policy agenda, I now move to an illustrative discussion of how a specific policy was badly enforced and inefficient. The discussion here again makes use of the documentary analysis and interview material gathered for this article.

The policy, as recommended by the IMF, was in the form of rapid privatisation. However, the model for this policy was to be chosen by the authorities in North Macedonia. The IMF's involvement in this privatisation process entailed the urgent restructuring of loss-making state-owned enterprises on the basis of advice that ran:

the economy needs urgent restructuring because the market cannot continue in this structure, $(\mathrm{STP}, \mathrm{KMI})^{13}$

and twenty loss-making companies were immediately restructured. However, when the respondents to my study reflected on the privatisation process they characterised it as unfair and corrupt.

The privatisation process started in 1995 with the then government selecting the management-employee buy-out (MEBO) model. This was not fully successful because the new private sector that had developed during the privatisation process, while small, had also been compelled to operate on a largely informal basis (Winkler 2000).

From the start of the transition process until 1999, 1467 enterprises were privatised and another 180 remained in the privatisation process. (TN)

Bartlett and Samardzija (2000) explain that the extensive privatisation programmes implemented in North Macedonia were not accompanied by appropriate measures, such as institutional development, market mechanism and private ownership, that would normally feature in a competitive market environment. Privatisation was, essentially, introduced too early without providing time for the other macroeconomic stability and price liberalisation policies to have become integrated in the system. Ignjatović (2012) has further argued that the MEBO model actually evolved into a predatory form of capitalism with corruptive elements creating a new class in society that became richer and more powerful 'overnight'. Thus, through the process of privatisation, 'politically connected tycoons acquired quasi-monopoly' positions (Bartlett and Samardzija 2000; WB).

A tough and inflexible negotiation with the IMF is pointed to by the research partners when reflecting on the choice of privatisation model. They highlight that:

the privatisation model was supported by the then two most powerful political parties in North Macedonia (KMG, STP, NIP, $\left.{ }^{14} \mathrm{KMI}\right)$

13 An academic, not politically active.

14 An academic, politically active in the early years of North Macedonia's independence. 
and, according to them:

there was no discussion with the IMF about which model of privatisation was most appropriate for the North Macedonian market. (STP)

The choice of the model of privatisation was further justified by 'the intention of maintaining very important political stability at that time and protecting North Macedonian capital from Albanian minority investors [the largest minority population]' (SP). Policy options were therefore assessed in the context of a consideration of how the long-term stability of the political leadership of North Macedonia would be affected (Haggard and Webb 1993). Some respondents who were closely involved in the reform process referred to the privatisation process as an:

inappropriate reform especially since the economy had not developed any market mechanism and private ownership. (NIP, NAM, ${ }^{15}$ IPF) ${ }^{16}$

Given that domestic elites were the major buyers of state-owned enterprises, this approach can also be perceived as delivering the opportunity for them to choose a model of privatisation that was most beneficial to themselves. According to some of the respondents in this study:

the reason for the chosen model of privatisation might have been to satisfy their [the political elite's] main interest: the privatisation process being completed in a way that they will reap the largest profits. (KMG)

It was argued that the government needed to find the 'best way' for the current managers to maintain their position and ownership of the enterprises as they would be the ones 'financing the political campaigns of the parties' (KMG). This relates to the point that, when reforms are not fully implemented, it is the economic and political elites who are, for the most part, the ones who benefit.

Even though several respondents acknowledged the unsuccessful privatisation process being pushed by the IMF, less critical respondents did not directly blame the IMF itself. Some of these less critical respondents justified their position with reference to local economic circumstances:

the increased unemployment would have existed even without the process of privatisation since it initially increased due to cutbacks in over-employed state-owned companies and the shrinkage of the market. ${ }^{17}$ (NIP, NAM, IPF)

In this way, the political elites sought to escape responsibility for the failure of the privatisation process on the basis of people's patriotism, pointing out that their actions had only been aimed at the well-being and prosperity of the country, i.e. the

16 Member of a public organisation.

17 The Yugoslav market was made up of a population of 24 million people while the North Macedonian market had a population of just two million. 
'greater good' (NP, TN), although it is also clear that the North Macedonian economy:

suffered the consequences of the rigid privatization process and the low competitiveness of the market. (IZC) ${ }^{18}$

Most of the enterprises were 'bought out for a small amount of money and were subject to restructuring which destroyed' an already vulnerable economy (IZC, $\mathrm{KMB}$ ). Therefore, the entire privatisation process was regarded by the more critical respondents as 'a painful internal process, non-transparent and assisting only tycoon criminals' (IZC, KMB, $\left.{ }^{19} \mathrm{KMG}\right)$. Ultimately respondents felt that:

it could have been completed in a more efficient and more fair way without dishonouring the rights of the people which did not participate in the privatisation, especially since all the people had been involved in building this capital: why were they restrained from contributing to the public capital? (IZC)

Even though the IMF had not suggested the model of privatisation to be implemented, the more critical respondents believe that 'it had an influence on the privatisation process in North Macedonia' (IZC, STP, KMG). They further believe that the IMF could have influenced this process by involving foreign financial organisations which would have 'evaluated capital in a transparent way' and that this would have led to 'an appropriate and more transparent revitalisation or preservation of enterprises' (IZC, KMG). However, the IMF's diagnostic abilities seem limited to following a superficial, unitary approach entailed by sticking doggedly to its 'one size fits all' approach despite the lack of appropriate institutional development or where this was seriously lagging. The IMF refused to recognise the cultural background and the corrupt nature of North Macedonian politics, leading to 'a corrupt privatisation process through which the owning structure' of enterprises changed but in which there was essentially no change in the 'management structure which obstructed the successful transformation of the private sector' (IZC). Furthermore, a significant number of these companies did not survive the transformation process; and those which did drastically decreased their production scope, leading to even higher unemployment rates (IZC).

\section{Conclusion}

This article focused on studying the extent to which the six key factors identified in the literature and which are both political (type of political regime, the process of transition and the party system) and economic (length of economic crisis, collective memory and external influence) play a role in creating an environment in which economic reforms can easily find support. In doing so, the article has uncovered the politics of economic reforms which are rooted in the relationship between national elites and other national political actors and has determined the importance of the

18 Member of a public organisation.

19 An academic, not politically active. 
role of the elites in obtaining support for neoliberal reforms. The findings and discussions in the article affirm that mass support for reforms is influenced by the attitude of the elites. Against this background, I argue that decision-makers have noticeable influence with which to model and have an impact on 'the space for reformist initiatives' (Grindle and Thomas 1989: 243). Through this process, a by-product was created in the reform process in North Macedonia in which the elites have supported policies from which they themselves benefit.

Based on the discussion, it is worth noting that support for economic reforms was associated with a kind of patriotism, portraying North Macedonia as a young and inexperienced country in need of the help of international organisations. This is frequently acknowledged (SAP, TAN). I reiterate here that the political and economic elites provided support for such reforms because they were the main beneficiaries of the ambiguous reform process that took place in the country, orchestrated by the IMF. Macroeconomic restructuring in North Macedonia, applied in line with the neoliberal policy agenda, also contributed to its prolonged transition. The 'free market' was presented as the solution to rebuilding a socialist economy in the middle of the wars generated by the disintegration of Yugoslavia. The destabilisation of an economic system, including the takeover of productive assets, the extension of markets and benefits accruing to certain elite groups constitute the real cause of the extended transition.

One limitation of the research summarised in this article may be that it focused on the key factors discussed in the literature and did not consider other important factors that might have been useful in the process of exploring the North Macedonian elite's involvement in the transition. However, the research was not aimed at adding to the known factors identified in the existing literature; instead, it aimed at uncovering the elite's involvement in supporting neoliberal reforms. This will nevertheless be useful for future research, with developing knowledge able to draw on the results of this study and an identification of other potentially important factors in this direction that may influence policy decisions regarding reforms. In addition, the study's aim was not to provide a toolkit of solutions that can be used, or a universal and standardised approach to detecting the support of elites in different economies. Rather, the six key political and economic factors reveal the role of the elites during the transition of North Macedonia towards a market economy and provoke further discussion on the intention of elites in small transition economies to push for reforms which are beneficial for them.

Thus, the main implications for policy-makers that this article is seeking to highlight is to be wary of the agenda set by foreign experts for small economies. It appears specifically mindful of the need for a deep understanding of the local context before deciding and implementing an appropriate context-specific policy programme. Significantly, the article analyses the vigour of the policy reform process and the institutional changes taking place in transition economies, as these were perceived by the actors intricately involved in such processes; however, at the same time, it is clear that policy reform is a process which differs from one country to the next in terms of making decisive approaches. While actors advocating economic pol- 
icy change may have achieved their objectives to a notable degree, there have been costs which, in this case, are reflected via the country's prolonged transition.

Current discussions in the political economy of policy reforms tend either to generalise insights from policy research or treat specific contexts as too peculiar and inapplicable. This article escapes these two extremes, offering fresh insights from a case study based on a range of various experiences that can be used as a stepping stone for further political economy research into policy reform. Such a study supports policy reformers in seeking more effective approaches toward change and economic development. Having said that, this article could provide a platform for conducting further comparative studies of the economy of North Macedonia in conjunction with other economies going through the process of transition. Such comparative studies can deliver new understanding of the way governments support certain reforms even though they disregard the context specifics by focusing on the by-products generated by such reforms.

Another recommendation for further research is of a more theoretical nature. This relates to the contribution of other economic and political factors that might be useful in separate contexts. As mentioned previously, the role of this article was not to develop new context-dependent aspects that provide a better explanation of the particular environment in which economic and political elites provide support for neoliberal reforms; rather, the discussion was intended to explore the extent to which the aspects discussed in the literature are accounted for in small economies, such as North Macedonia. Even so, future research could focus on using the same elements in different contexts with the aim of expanding and adding new components which might further account for the idea of elite support for economic reform alongside encouraging a fresh perspective on the general area of pro-market policy-making.

\section{References}

Abdullai, J. and L. Sinani (2012) 'Political culture and policy-making after the fall of communism in Macedonia’ Revista de Ştiinţe Politice 33-34: 29-39.

Ackoska, V (2006) ‘Sovremenata Makedonska drzava niz dve istoriski tranzicii’ Megunaroden seminar za jazik i cultura.

Acemoglu, D. and J. A. Robinson (2008) 'Persistence of power, elites, and institutions' American Economic Review 98(1): 267-93.

Alesina, A. and H. Rosenthal (1995) Partisan politics, divided government, and the economy Cambridge: Cambridge University Press.

Armijo, L. E. and P. Faucher (2002) 'We have a consensus: Explaining political support for market reforms in Latin America' Latin American politics and society 44(2): 1-40.

Aslund, A (2000) Why has Russia's economic transition been so arduous? Carnegie Europe paper accessed 22 November 2021 at: https://carnegieeurope.eu/publications $/ ? \mathrm{fa}=201$.

Åslund A, P. Boone and S. Johnson (2002) Escaping the under-reform trap IMF Staff Papers, 48. 
Bacanovic, O. and N. Jovanova (2011) 'Tranzicija, mladi i kriminalitet' 20 years since the breaking-up of SFRY Belgrad: Goragraf.

Baccini, L and J. Urpelainen (2014) 'International institutions and domestic politics: can preferential trading agreements help leaders promote economic reform? Journal of Politics 76(1): 195-214.

Baker, A (2003) 'Why is trade reform so popular in Latin America? A consumptionbased theory of trade policy preferences' World Politics 55(3): 423-455.

Bartlett, W (2009) 'Economic development in the European super-periphery: Evidence from the Western Balkans' Economic Annals 54(181): 21-44.

Bartlett, W and V. Samardzija (2000) 'The reconstruction of South East Europe, the stability pact and the role of the EU: An overview' MOST 2: 245-263.

Barro, R (1997) Determinants of economic growth: a cross-country empirical study Cambridge, MA: MIT Press.

Besley, T, T, Persson and D. Sturm (2005) Political competition and economic performance: theory and evidence from the United States NBER Working Paper 11484, Cambridge, MA: NBER.

Bratton, M and R. Mattes (2001) 'Support for democracy in Africa: Intrinsic or instrumental?’ British Journal of Political Science 31: 447-474.

Chhibber, P and S. Eldersveld (2000) 'Local elites and popular support for economic reform in China and India' Comparative Political Studies 33(3): 350-373.

Chossudovsky, M (1997) 'Dismantling former Yugoslavia, recolonizing Bosnia' Capital and Class 21(2): 1-12.

Desai, R. M and A. Olofsgård (2006) 'Constitutionalism and credibility in reforming economies' Economics of Transition 14: 479-504.

Dmitrijevich, D and G. Macesich (1973) Money and finance in contemporary Yugoslavia New York: Praeger.

Estrin, S (1991) 'Yugoslavia: The case of self-managing market socialism' The Journal of Economic Perspectives 5(4): 187-194.

Gibson, E (1997) 'The populist road to market reform: Policy and electoral coalitions in Mexico and Argentina' World Politics 49(3): 339-370.

Goldman, M. I (1994) Lost opportunity: Why economic reforms in Russia have not worked New York: W. W. Norton.

Grindle, M. S and J. W. Thomas (1989) 'Policy makers, policy choices, and policy outcomes: The political economy of reform in developing countries' Policy sciences 22(3): 213-248.

Grugel, J and P. Riggirozzi (2012) 'Post-neoliberalism in Latin America: Rebuilding and reclaiming the state after crisis' Development and Change 43(1): 1-21.

Habib, A and V. Padayachee (2000) 'Economic policy and power relations in South Africa's transition to democracy’ World Development 28(2): 245-263. 
Haggard, S (1995) Developing nations and the politics of global integration Brookings Institution Press.

Haggard, S and R. R. Kaufman (1990) The political economy of inflation and stabilization in middle-income countries Washington DC: World Bank.

Haggard, S, R. Kaufman and S. B. Webb (1991) Democracy, dictatorship, and inflation in middle-income countries Washington DC: World Bank.

Haggard, S and S. B. Webb (1993) 'What do we know about the political economy of economic policy reform?’ The World Bank Research Observer 8(2): 143-168.

Hameiri, S and L. Jones (2017) 'Beyond hybridity to the politics of scale: International intervention and "local” politics' Development and Change 48: 54-77.

Harvey, D (2007) A brief history of neoliberalism Oxford: Oxford University Press.

Hellman, J. S (1998) 'Winners take all: the politics of partial reform in postcommunist transitions’ World Politics 50(2): 203-234.

Ignjatović, M (2012) 'Labour market flexibility and security in the EU' Teorija $i$ praksa 49(6): 901-921.

Johnson, R, S. Darbar and C. Echeverria (1997) 'Sequencing capital account liberalization: lessons from experiences in Chile, Indonesia, Korea, and Thailand' Working Paper WP/97/157, Washington DC: International Monetary Fund.

Kahler, M (1992) 'External influence, conditionality and the politics of adjustment' in Stephan Haggard and Robert Kaufman (Eds) The politics of economic adjustment: International constraints, distributive politics, and the state Princeton: Princeton University Press.

Kohlscheen, Emanuel (2005) Sovereign risk: constitutions rule University of Warwick Department of Economics No. 731, Coventry: University of Warwick.

Lolos, S. E (2009) 'The effect of EU structural funds on regional growth: assessing the evidence from Greece, 1990-2005' Economic Change and Restructuring 42(3): 211-228.

Mansfield, E. D and J. C. Pevehouse (2006) 'Democratization and international organizations’ International Organization 60(1): 137-167.

Mastilica, M (1990) 'Health and social inequalities in Yugoslavia' Social Science and Medicine 31(3): 405-412.

Micevska, M, D. Eftimoski and T. Petkovska-Mircevska (2002) Economic growth of the Republic of Macedonia: Experiences and policy recommendations World Bank Global Research Project: Explaining Growth, Washington DC: World Bank.

Moore, M (1997) 'Leading the left to the right: Populist coalitions and economic reform' World Development 25(7): 1009-1028. 
Mulligan, C. B, R. Gil and X Sala-i-Martin (2004) 'Do Democracies Have Different Public Policies than Nondemocracies?' Journal of Economic Perspectives 18(1): $51-74$.

Naughton, B (1994) 'Chinese institutional innovation and privatization from below' American Economic Review 84(2): 266-270.

Nelson, J (1990) Economic crisis and policy choice: The politics of adjustment in the third world Princeton: Princeton University Press.

Nineski, B (2001) Izborite, mediumite i partiite vo Makedonija 1990-2000.

North, D. C (1990) Institutions, institutional change and economic performance Cambridge: Cambridge University Press.

Olson, M (1990) Autocracy, democracy, and prosperity University of Maryland Department of Economics.

Persson, T and G. Tabellini (2006) Democratic capital: the nexus of political and economic change NBER Working Paper 12175, April, Cambridge, MA: NBER.

Pop-Eleches, Grigore (2009) From Economic Crisis to Reform: IMF Programs in Latin American and Eastern Europe Princeton: Princeton University Press.

Przeworski, A (1996) 'Public support for economic reforms in Poland' Comparative Political Studies 29(5): 520-543.

Risteski, S and M. Trpkova (2010) 'Global economic crisis and its impact on the western Balkan countries labor markets' Revista Tinerilor Economişti 15: 96-107.

Roberts, K. M and M. Arce (1998) 'Neoliberalism and lower-class voting behavior in Peru' Comparative Political Studies 31(2): 217-246.

Rodrik, D (1996) 'Understanding economic policy reform' Journal of Economic Literature 34(1): 9-41.

Rodrik, D (2014) 'Why an African growth miracle is unlikely' The Milken Institute Review, 4th Quarter, pp. 42-54.

Ruzin, N (1999) Sustav socijalne zastite u Republici Makedoniji accessed 22 November 2021 at: http://hrcak.srce.hr/file/47215.

Sachs, J. D (1995) ‘Consolidating capitalism’ Foreign Policy 98: 50-64.

Schoenman, R (1995) 'Divide and rule schemes in the Balkans' The Organiser 11 September.

Sen, R (2015) 'Diverse methods of imperialism during the post-colonial era' International Journal of African and Asian Studies 8: 22-25.

Shenkar, O and M. A. Von Glinow (1994) 'Paradoxes of organizational theory and research: Using the case of China to illustrate national contingency' Management Science 40: 56-71. 
Shleifer, A (1997) 'Government in transition' European Economic Review 41(3): 385-410.

Shleifer, A and D. Treisman (2000) Without a map: Political tactics and economic reform in Russia Cambridge: MIT Press.

Sikkink, K (1990) Ideas and institutions: Developmentalism in Brazil and Argentina Ithaca: Cornell University Press.

Shepsle, K. A and B. Weingast (1984) 'Legislative politics and budget outcomes' in Gregory B. Mills and John L. Palmer (Eds) Federal budget policy in the $1980 \mathrm{~s}$ Washington DC: Urban Institute.

Snider, L (1990) 'The political performance of third world governments and the debt crisis’ American Political Science Review 84(4): 126-380.

Stiglitz, J (2002) Globalization and its discontents New York: W. W. Norton.

Vreeland, J. R (2003) The IMF and Economic Development Cambridge: Cambridge University Press.

Webb, S. B and K. Shariff, K (1992) 'Designing and implementing adjustment programs' In Vittorio Corbo, Stanley Fischer and Steven B. Webb (Eds) Adjustment lending revisited: Policies to restore growth World Bank symposium, Washington, DC: World Bank.

Winkler, A (2000) 'Private and financial sector development in transition economies: the case of Macedonia' Economics Systems 24(3): 257-284.

Viktorija Mano is Head of Collaborative Partnerships at the Faculty of Business and Law, University of Roehampton, LONDON SW15 5SL. e-mail: Viktorija.Mano@ro ehampton.ac.uk.

\section{(9) $(\Theta \Theta \Theta$ \\ (C) Viktorija Mano}


